\title{
PRIVATISASI STRUKTUR KEPEMILIKAN, DAN KINERJA BUMN DI INDONESIA
}

\author{
Abdul Kadir Usri \\ STIE Malangkucecwara Malang
}

\begin{abstract}
One of the measures to improve the productivity and efficiency of BUMN isprivatization. Privatization is considered successful if it can improve efficiency, decrease the price or service improvements and performance enhancements. The population in this study are all state-owned enterprises to be privatized using the Initial Public Offering (IPO) from the period 1991 to 2004. The analysis method used in this research is multiple line arregression. The results showed (1) public ownership is partially significant effect on the performance of BUMN after privatization as measured by ROS, ROI, ROE, and SALEFF, so the proposed hypothesis proved correct. The influence of public ownership of the largest BUMN performance after privatization is shown by the measured performance using ROS and the smallest is SALEFF. (2) The prospective share holders with ROS great interest, as this is one indicator of the success of a company, the company's sales performance improvement and management can manage BUMN well after privatization (3) SALEFF is a measure of performance (efficiency of operations) thats hows the efficiency of sales or revenues, measured using a weighing between sales or income by the number of employees BUMN privatization proceeds. The prospective share holders interested SALEFF great because it shows more efficiency operation BUMN privatization results, which compare sales or revenue to the number of employees who work in there.
\end{abstract}

Keywords: privatization, ownership structure, ROS, ROI, ROE, SALEFF

Badan Usaha Milik Negara atau BUMN yang seluruh atau sebagian besar modalnya berasal dari kekayaan negara yang dipisahkan, merupakan salah satu pelaku ekonomi dalam sistem perekonomian nasional di samping swasta dan koperasi. Dalam sistem perekonomian nasional, BUMN ikut menghasilkan barang dan/ atau jasa yang diperlukan dalam rangka mewujudkan sebesar-besarnya kemakmuran masyarakat. Sebagai implementasi kewajiban pemerintah guna menyediakan barang dan/atau jasa tertentu untuk memenuhi kebutuhan masyarakat, tujuan BUMN sebagai pendorong perkembangan dan pertumbuhan ekonomi dalam rangka pembangunan nasional dalam rangka pembangunan nasional dapat tercapai.

Dalam kenyataannya, walaupun BUMN telah mencapai tujuan awal sebagai pendorong perkembangan dan pertumbuhan ekonomi, namun tujuan tersebut dicapai dengan biaya yang relatif tinggi. Kinerja perusahaan dinilai belum memadai, BUMN belum sepenuhnya dapat menyediakan barang dan/ atau jasa yang bermutu tinggi bagi masyarakat dengan harga yang terjangkau serta belum mampu berkompetisi dalam persaingan bisnis global (Pandu Patriadi, http://www.google.com/privatisasi).
Sejalan dengan hal tersebut di atas, maka untuk mengatasinya pemerintah perlu menigkatkan produktivitas dan efisiensi BUMN. Peningkatan produktivitas dan efisiensi BUMN dapat dilakukan dengan cara restrukturisasi dan privatisasi perusahaan. Restrukturisasi adalah upaya yang dilakukan dalam rangka penyehatan BUMN yang merupakan salah satu langkah strategis untuk memperbaiki kinerja dengan meningkatkan nilai perusahaan. Restrukturisasi, dimaksudkan bagi perusahaan yang usahanya berkaitan dengan kepentingan umum. Sedangkan bagi BUMN yang tujuannya memupuk keuntungan dan bergerak dalam sektor yang kompetitif didorong untuk privatisasi. Oleh sebab itu, privatisasi hanya dapat dilakukan terhadap BUMN yang berbentuk Persero. Hal ini dikarenakan selain dimungkinkan oleh ketentuan dibidang pasar modal, juga karena pada umumnya hanya Persero yang telah bergerak dalam sektor-sektor yang kompetitif. Namun demikian, dalam Persero melakukan restrukturisasi, maksudnya adalah untuk mempermudah pelaksanaan privatisasi. Selain untuk meningkatkan produktivitas dan efisiensi BUMN, khusunya Persero, privatisasi dilakukan juga karena 
untuk menutupi defisit Anggaran Pendapatan dan Belanja Negara (APBN).

Privatisasi Persero dilakukan tidak mengakibatkan kendali atau kedaulatan Negara atau BUMN yang bersangkutan menjadi berkurang atau hilang, karena Negara tetap menjalankan fungsi penguasaan melalui regulasi sektoral tempat Persero yang diprivatisasi melaksanakan kegiatan usahanya. Privatisasi pada dasarnya bertujuan untuk meningkatkan peran Persero dalam upaya meningkatkan kesejahteraan umum dengan memperluas kepemilikan masyarakat atas Persero serta untuk menunjang stabilitas perekonomian nasional. Privatisasi dilakukan dengan memperhatikan prinsip-prinsip transparansi, kemandirian, akuntabilitas, pertanggungjawaban, dan kewajaran.

Privatisasi dinilai berhasil jika dapat melakukan efisiensi, terjadi penurunan harga atau perbaikan pelayanan. Selain itu, privatisasi memang bukan hanya mengangkat masalah ekonomi semata, melainkan juga menyangkut masalah transformasi sosial. Di dalamnya menyangkut landasan konstitusional privatisasi, sejauh mana privatisasi bisa diterima oleh masyarakat, karyawan dan elite politik (parlemen) sehingga tidak menimbulkan gejolak. Munculnya penolakan atau demo dari para stakeholder, dengan demikian terdapat beberapa hal yang belum dipersiapkan dengan matang. Mata rantai dalam proses privatisasi ada yang terlepas sehingga terjadi penolakan dan menimbulkan konflik yang meluas. (Pandu Patriadi, http://www. google.com/privatisasi).

Beberapa hal mengenai langkah privatisasi membutuhkan persiapan secara memadai seperti mempertimbangkan langkah-langkah restrukturisasi BUMN sebelum dilakukan privatisasi yang kemudian justru menjadikan BUMN tersebut beralih menuju perusahaan modal asing. Selain itu, perlu dilakukan sosialisasi sebelum dilakukan privatisasi sehingga tidak menimbulkan gejolak, termasuk mempersiapkan landasan konstitusionalnya yang khusus mengatur mengenai privatisasi.

Pengaturan mengenai privatisasi terdapat dalam Undang-Undang Nomor 19 Tahun 2003 Tentang Badan Usaha Milik Negara (Selanjutnya disebut dengan UU BUMN), dan peraturan lebih lanjutnya dalam peraturan pemerintah.

Pada periode 1991-2001 pemerintah Indonesia 14 kali memprivatisasi BUMN dengan jumlah BUMN yang diprivatisasi 12. Pada periode 2001-2006 pemerintah juga 14 kali memprivatisasi BUMN dengan jumlah BUMN yang diprivatisasi sebanyak 10 .
Sedangkan untuk tahun 2008 pemerintah memprivatisasi 37 BUMN dengan penjualan seluruh saham 14 buah BUMN industri, 12 BUMN dijual dengan kepada investor strategis, dan beberapa BUMN lagi harus disertai dijual kepada asing. (http://jurnal-ekonomi.org/ 2008/02/06/bom-privatisasi-Indonesia-2008/).

Semakin bertambahnya BUMN yang diprivatisasi oleh pemerintah Indonesia, diharapkan mampu mendongkrak kinerja (performance) dengan struktur kepemilikan, bahwa perbandingan kepemilikan publik (public ownership atau public share) lebih besar dari kepemilikan pemerintah (goverment ownership atau state share).

Dengan melihat latar belakang diatas maka tujuan dari penelitian ini ialah untuk mendeskripsikan dan menganalisis besarnya pengaruh kepemilikan publik terhadap kinerja BUMN Indonesia setelah privatisasi.

\section{Badan Usaha Milik Negara (BUMN)}

Undang-Undang No.19 Tahun 2003 tentang Badan Usaha Milik Negara menyatakan bahwa BUMN adalah badan usaha yang seluruh atau sebagian besar modalnya dimiliki oleh negara melalui penyertaan secara langsung yang berasal dari kekayaan Negara yang dipisahkan. Dari pengertian tersebut terdapat beberapa unsur BUMN yaitu: (1) merupakan badan usaha (2) seluruh atau sebagian modalnya dimiliki Negara melalui penyertaan secara langsung (3) kekayaan berasal dari Negara yang dipisahkan.

Dalam UU BUMN bentuk usaha badan usaha milik Negara, terbagi menjadi dua, perusahaan umum (Perum) dan Perusahaan Perseroan (Persero). Perum sebagai perusahaan Negara lebih menguntungkan pelayanan demi kemanfaatan kepentingan umum berdasarkan prinsip pengelolaan perusahaan dan tidak semata-mata untuk mengejar keuntungan. Namun untuk kelangsungan perusahaan, Perum tetap harus mengejar keuntungan walaupun tidak sebagai tujuan utama. Sedangkan perusahaan perseroan (Persero) merupakan badan usaha milik Negara yang berbentuk perseroan terbatas, dengan demikian berlaku prinsipprinsip perseroan terbatas sebagaimana diatur dalam Undang-Undang Nomor 1 Tahun 1995 tentang Perseroan Terbatas. Persero didirikan dengan tujuan menyediakan barang dan/atau jasa yang bermutu tinggi dan berdaya saing kuat, serta mengejar keuntungan guna meningkatkan nilai perusahaan.

\section{Privatisasi}

Privatisasi adalah proses kejadian atau menstransfer kepemilikan sebuah bisnis, perusahaan, lembaga 
atau pelayanan publik dari sektor publik (pemerintah) untuk sektor swasta (bisnis). Dalam arti yang lebih luas, privatisasi mengacu pada transfer pemerintah setiap fungsi ke sektor swasta termasuk fungsi pemerintahan seperti pengumpulan pendapatan dan penegakan hukum (www.wikipedia.com).

Maksud dan tujuan privatisasi berdasarkan Pasal 74 UU Nomor 19 Tahun 2003 yaitu untuk: (1) Memperluas kepemilikan masyarakat atau Persero (2) Meningkatkan efisiensi dan produktivitas perusahaan (3) menciptakan struktur keuangan dan manajemen keuangan yang baik/kuat (4) Menciptakan struktur industri yang sehat dan kompetitif (5) menciptakan Persero yang berdaya saing dan berorientasi global (6) menumbuhkan iklim usaha, ekonomi makro dan kapasitas pasar.

Berdasarkan Pasal 78 UU No.19 Tahun 2003, Privatisasi dilaksanakan dengan cara: (1) penjualan saham berdasarkan ketentuan pasar modal (2) Penjualan saham langsung kepada Investor (3) Penjualan saham kepada manajemen dan/atau karyawan yang bersangkutan.

Sementara itu, dengan dilakukannya privatisasi BUMN, akan memberikan manfaat sebagai berikut (http://cafe-ekonomi.blogspot.com/2009/05/ restrukturisasi-dan-privatisasi-bumn.html): (1) BUMN akan menjadi lebih transparan, sehingga dapat mengurangi praktek KKN, (2) Manajemen BUMN menjadi lebih independen, termasuk bebas dari intervensi birokrasi, (3) BUMN akan memperoleh akses pemasaran ke pasar global, selain pasar domestik, (4) BUMN akan memperoleh modal ekuitas baru berupa fresh money sehingga pengembangan usaha menjadi lebih cepat (5) BUMN akan memperoleh Transfer of Teknology, terutama teknologi proses produksi, (6) Terjadi transformasi Corporate Culture dari budaya birokratis yang lamban menjadi budaya korporasi yang lincah (7) Mengurangi defisit APBN karena dana yang masuk sebagian untuk menambah kas APBN (8) BUMN akan mengalami peningkatan kinerja operasional/keuangan, karena pengelolaan perusahaan lebih efisien.

\section{Struktur Kepemilikan}

Badan Usaha Milik Negara atau BUMN yang seluruh atau sebagian besar modalnya berasal dari kekayaan Negara yang dipisahkan. Kepemilikan pemerintah (State Ownership) adalah besarnya saham yang dimiliki pemerintah (saham mayoritas) atas suatu perusahaan (BUMN) yang dikelola oleh pemerintah baik berbentuk Perum maupun Perjan. Dengan dilakukannya privatisasi pada BUMN, persentase saham yang dimiliki pemerintah akan menjadi berkurang dan beralih menjadi milik publik (masyarakat).

\section{Kinerja (Performance)}

Kinerja (performance) merupakan hasil dari aktivitas yang dilakukan perusahaan dalam suatu periode. Dalam penelitian ini kinerja dikelompokan menurut beberapa peneliti terdahulu, antara lain: Boubakri and Cosset (1995) membagi performance menjadi: (1) Profitability, terdiri dari ROS, ROE, ROI, (2) Operating Efficiency terdiri dari Sales Efficiency; Net Income Efficiency, (3) Capital Investment terdiri dari Capital Expenditures/Sales; Capital Expenditures/Total Asset, (4) Output yaitu Nominal Sales/Consumer Price Index (5) Employment, yaitu Number of Employees (5) Leverage terdiri dari Total Debt/Total Assets; Long Term Debt/Equity, (6) Dividence Policy terdiri dari Cash Dividend/Sales; Cash Dividend/Net Income.

D'Souza and Megginson (1999) membagi performance menjadi: (1) Profitability terdiri dari ROS; ROE; ROI, (2) Sales Efficiency, terdiri dari Sales/ Total Employment; Net Income/Total Employement, (3) Capital Investmen, terdiri dari Capital Expenditure to Sales; Capital Expenditure to Total Asset, (4) Output yaitu Nominal Sales/Consumer Price Index, (5) Employement, yaitu Total Number Of Employees, (6) Leverage, yaitu Total Debt to Total Asset (7) Dividend to Sales, yaitu Dividend/Sales.

Huang and Song (2002) membagi performance menjadi ROS; ROE; ROI; Sales Efficiency; Net Income Efficiency; Aset Turnover; Real Sales; Total Number Of Employees; Debt to Assets Ratio; Long Term Debt to Equity Ratio; Ratio Of Dividend to Sales; Devidend Payout.

\section{METODE}

\section{Rancangan Peneliatian}

Sesuai dengan tujuan yang ingin dicapai dalam penelitian ini, yaitu menjelaskan hubungan dan pengaruh beberapa variabel yang sudah ditetapkan, maka penelitian yang digunakan adalah penelitian menurut tingkat eksplanasi atau tingkat penjelasan, yaitu "bagaimana variabel-variabel yang diteliti akan menjelaskan obyek yang diteliti melalui data yang terkumpul" (Sugiyono, 2001:6). 
Jenis data yang digunakan dalam penelitian ini adalah data kuantitatif, yaitu data yang berbentuk angka, berupa kepemilikan pemerintah (goverment ownership) dan kinerja (performance) BUMN setelah privatisasi. Untuk sumber data yang dipergunakan dalam penelitian ini adalah data sekunder, yaitu: (1) Laporan keuangan BUMN hasil privatisasi yang menjadi sampel selama periode penelitian (2) Data perimbangan kepemilikan saham antara buplik dan pemerintah dari BUMN hasil privatisasi yang menjadi sampel selama periode penelitian.

Dilihat dari waktu pengambilan data (Observasi) data diambil secara pooling, yaitu gabungan data runtut waktu (time series) dan data cross section. Periode penelitian dilakukan selama empat tahun (2007-2010). Sedangkan populasi dalam penelitian ini adalah seluruh BUMN yang diprivatisasi menggunakan metode Intial Public Offering (IPO) mulai periode 1991 sampai dengan 2004, sebanyak 13 BUMN.

Dalam penelitian ini diteliti seluruh elemen populasi atau jumlah sampel sama dengan jumlah populasi, yang disebut dengan sensus. Indriantoro dalam Supomo (2002:117) menyatakan bahwa digunakannya penelitian sensus, jika elemen-elemen populasi relatif sedikit. Tabel berikut ini menunjukkan jumlah sampel yang dipergunakan dalam penelitian ini, yaitu BUMN yang melakukan privatisasi melalui Intial Public Offering (IPO) di Bursa Efek Indonesia (BEI) pada tabel 1. variabel yang digunakan dalam penelitian ini ditunjukkan pada tabel 2.

\section{Metode Analisis Data}

Metode analisis dalam penelitian ini digunakan Analisis Regresi Berganda. Model analisis ini merupakan analisis yang bersifat kuantitatif, yang digunakan untuk mengetahui sejauhmana besarnya pengaruh antara variabel bebas dengan variabel terikat. Spesifikasi model yang digunkan dalam penelitian ini adalah:

$\mathrm{ROS}=\beta \mathrm{o}+\beta_{1} \mathrm{SS}+\beta_{2} \mathrm{PS}+\beta_{3} \mathrm{SIZE}+\beta_{4} \mathrm{LEV}+\varepsilon \mathrm{j}(1)$

$\mathrm{ROI}=\beta \mathrm{O}+\beta_{1} \mathrm{SS}+\beta_{2} \mathrm{PS}+\beta_{3} \mathrm{SIZE}+\beta_{4} \mathrm{LEV}+\varepsilon \mathrm{j}(2)$

$\mathrm{ROE}=\beta \mathrm{o}+\beta_{1} \mathrm{SS}+\beta_{2} \mathrm{PS}+\beta_{3} \mathrm{SIZE}+\beta_{4} \mathrm{LEV}+\varepsilon \mathrm{j}(3)$

$\mathrm{SALEFF}=\beta \mathrm{O}+\beta_{1} \mathrm{SS}+\beta_{2} \mathrm{PS}+\beta_{3} \mathrm{SIZE}+\beta_{4} \mathrm{LEV}+\varepsilon \mathrm{j}(4)$

Keterangan:

$\begin{array}{ll}\text { ROS } & \text { : Return Of Asset } \\ \text { ROI } & \text { : Return Of Investment } \\ \text { ROE } & \text { : Return On Equity } \\ \text { SALEFF } & \text { : Sales Efficiency } \\ \beta \text { Bo } & : \text { Parameter Intercept Regresi } \\ \beta_{1} & : \text { Parameter Slope Regresi } \\ \text { SS } & : \text { State Share } \\ \text { PS } & : \text { Public Share } \\ \text { SIZE } & : \text { Ukuran Perusahaan } \\ \text { LEV } & : \text { Hutang Perusahaan } \\ \varepsilon & : \text { variabel pengganggu }\end{array}$

Selanjutnya dilakukan Uji F adalah menguji keberartian koefisien regresi (signifikan) secara keseluruhan, dengan menggunakan rumus Gujarati (1998: 120) sebagai berikut:

Tabel 1. Sampel Penelitian

\begin{tabular}{llc}
\hline No & \multicolumn{1}{c}{ BUMN RI (BUMN Tbk.) } & Tahun Priva tisasi Melalui IPO \\
\hline 1 & PT.Semen Gresik, Tbk & 1991 \\
2 & PT. Indosat & 1994 \\
3 & PT. Tambang Timah, Tbk & 1995 \\
4 & PT.Telkom, Tbk & 1995 \\
5 & PT. Bank BNI, Tbk & 1996 \\
6 & PT.Aneka Tambang, Tbk & 1997 \\
7 & PT.Kimia Farma, Tbk & 2001 \\
8 & PT.Indofarma, Tbk & 2001 \\
9 & PT.Tambang Batu Bara Bukit Asam, Tbk & 2002 \\
10 & PT.Bank Mandiri, Tbk & 2003 \\
11 & PT.Bank BRI, Tbk & 2003 \\
12 & PT.Perusahaan Gas Negara, Tbk & 2003 \\
13 & PT. Adhi Karya, Tbk & 2004 \\
\hline
\end{tabular}

Sumber: diolah peneliti

\section{Definisi Operasional Variabel}

Variabel yang digunakan dalam penelitian ini terbagi menjadi variabel terikat, variabel bebas, dan variabel kontrol. Operasionalisai dari masing-masing

\author{
$\mathrm{F}: \frac{\mathrm{ESS} /(\mathrm{K}-1)}{\mathrm{RSS} /(\mathrm{N}-\mathrm{K})}$ \\ $\mathrm{F}=$ Nilai $\mathrm{F}_{\text {hitung }}$ \\ ESS $=$ Explained Sum Square (rata-rata kuadrat regresi) \\ RSS = Residual Sum Square (rata-rata kuadrat residual)
}


Tabel 2. Ringkasan Definisi Operasional Variabel Penelitian

\begin{tabular}{|c|c|c|}
\hline Variabel & Pengukuran & Notasi \\
\hline \multicolumn{3}{|c|}{ Variabel Terikat } \\
\hline \multicolumn{3}{|c|}{ 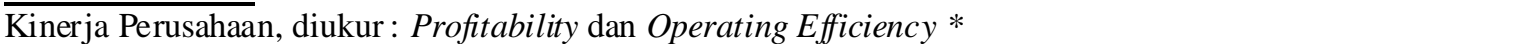 } \\
\hline & Return on Sales $=$ Net Income $/$ Sales & ROS \\
\hline \multirow[t]{2}{*}{ Profitability } & Return on Investmen $=$ Net Income/ Total Asset & ROI \\
\hline & Retun On Equity = Net Incomel Equity & $\mathrm{ROE}$ \\
\hline Operating Efficiency & Sales Efficiency = Sales/ Number Of Employess & SALEFF \\
\hline \multicolumn{3}{|c|}{ Variabel Bebas } \\
\hline \multicolumn{3}{|c|}{ Struktur kepemilikan, diukur dengan : State Share dan Public Share ** } \\
\hline State Share & Persentase kepemilikan pemerintah & SS \\
\hline Public Share & Persentase kepemilkan publik & PS \\
\hline \multicolumn{3}{|l|}{ Variabel Kontrol } \\
\hline \multicolumn{3}{|c|}{ 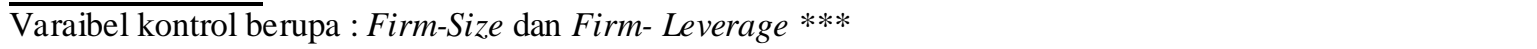 } \\
\hline Firm-Size & Logaritma Total Asset & SIZE \\
\hline Firm-Leverage & Total Debt/ Total Assets & LEV \\
\hline
\end{tabular}

Sumber: Diolah

* = (D'Souza and Megginson, 1999; Huang and Song, 2002

$* *=$ (D'Souza and Megginson, 1999; Huang and Song, 2002

$* * *=($ Sun, Tong, and Tong, 2002; Li, et.al 2007)

$\mathrm{k} \quad=$ banyaknya variabel bebas termasuk konstanta

$\mathrm{n} \quad$ = jumlah data

Uji F ANOVA dilakukan dengan membandingkan probability value (tingkat signifikansi) yang ditetapkan untuk penelitian ini (sebesar $\alpha=0.05$ atau 5\%) dengan probability value hasil penelitian. Kriteria pengujian dilakukan sebagai berikut (Santoso, 2001): (1) Apabila probability value hasil penelitian $<\alpha(0.05)$, maka Ho ditolak dan Ha diterima. (2) Apabila Probability Value hasil penelitian $>\alpha(0.05)$, maka Ho diterima dan Ha ditolak.

Sedangkan untuk mengukur sejauh mana ketetapan model tersebut dipergunakan dalam penelitian ini, dapat pula dilihat dari besarnya koefisien determinasi berganda $\left(\mathrm{R}^{2}\right)$. Jika $\mathrm{R}^{2}$ mendekati (1), maka dikatakan semakin kuat model itu dalam menerangkan variasi variabel terikat dan semakin mendekati nol (0), maka semakin lemah model untuk menjelaskan variabel terikatnya.

Pengujian secara parsial dilakukan dengan menggunakan uji t. Uji t, yaitu untuk menguji signifikansi pengaruh masing-masing variabel bebas terhadap variabel terikat dengan rumus Gujarati (2003) sebagai berikut:

$\mathrm{t}=\frac{\mathrm{bi}}{\text { Sebi }}$

bi : Koefisien Regresi

Sebi : Standart Error Koefisien Regresi

Uji t dilakukan dengan membandingkan probability value (tingkat signifikansi) yang ditetapkan untuk penelitian ini (sebesar $\alpha=0.05$ atau 5\%) dengan pro-

Docner, et.al. 2005; Mathur and Wanrapee, 2007).

Docner, et.al. 2005; Mathur and Wanrapee, 2007).

bability value hasil penelitian. Kriteria pengujian dilakukan sebagai berikut (Santoso, 2001): (1) Apabila probability value hasil penelitian $<\alpha(0.05)$ maka Ho ditolak dan Ha diterima, (2) Apabila probability value hasil penelitian $>\alpha(0.05)$, maka Ho diterima dan Ha ditolak.

\section{HASIL DAN PEMBAHASAN}

\section{Uji Hipotesa}

Hipotesis yang diajukan dalam penelitian ini dinyatakan bahwa kepemilikan pemerintah mempengaruhi kinerja BUMN setelah privatisasi. Kinerja (performance) perusahaan dalam penelitian ini di ukur menggunakan profitabilitas, berupa ROS, ROI, dan ROE serta efisiensi operasi berupa SALEFF. Oleh karena itu untuk menguji hipotesis yang diajukan dalam penelitian ini dilakukan untuk setiap variabel kinerja, yaitu ROS, ROI, ROE dan SALEFF.

\section{Kinerja yang Diukur Menggunakan ROS}

Hasil perhitungan pada Tabel 3 menunjukan bahwa signifikansi $\mathrm{F}$ bernilai 0.000 lebih kecil dari $\mathrm{Q}$ (0.05) yang berarti semua variabel bebas berpengaruh signifikan terhadap variabel terikat, sehingga dapat dikatakan bahwa Ho ditolak atau Ha diterima atau dengan kata lain PS, SS, LEV, dan SIZE secara simultan mempunyai pengaruh signifikan terhadap ROS.

Sejauh mana ketetapan model penelitian yang dipergunakan dalam penelitian ini, diukur menggunakan koefisien determinasi berganda $\left(\mathrm{R}^{2}\right)$, seperti ditunjukan pada Tabel 4. Jika $\mathrm{R}^{2}$ mendekati (1), maka 
Tabel 3. Hasil Analisis Regresi Linier Berganda-Uji F (Variabel Terikat ROS)

ANOVA $^{b}$

\begin{tabular}{llrrrrr}
\hline Model & & Sum of Squares & Df & Mean Square & F & Sig. \\
\hline 1 & Regression & .280 & 4 & .070 & 14.224 & $.000^{\mathrm{a}}$ \\
& Residual & .231 & 47 & .005 & & \\
\hline \multicolumn{2}{l}{ Total } & .510 & 51 & & & \\
\hline
\end{tabular}

a. Predictors: (Constant), LEV, SS, PS,SIZE

b. Dependent Variable: ROS

Tabel 4 .Hasil Analisi Regresi Linier Berganda- R Square (Variabel Terikat ROS)

Model Summary ${ }^{\text {b }}$

\begin{tabular}{|c|c|c|c|c|c|}
\hline Model & $\mathbf{R}$ & R Square & $\begin{array}{l}\text { Adjusted R } \\
\text { Square }\end{array}$ & $\begin{array}{l}\text { Std. Error of the } \\
\text { Estimate }\end{array}$ & Durbin-Watson \\
\hline 1 & $.740^{\mathrm{a}}$ & .548 & .509 & .0700910450 & 1.922 \\
\hline
\end{tabular}

a. Predictors: (Constant), LEV, SS, PS, SIZE

b. Dependent Variable: ROS

dikatakan semakin kuat model itu dalam menerangkan variasi variabel dependen dan semakin mendekati nol (0), maka semakin lemah model untuk menjelaskan variabel dependennya. Dari hasil perhitungan pada Tabel 4 diperoleh nilai $\mathrm{R}^{2}$ sebesar 0.548 (54.8\%). Hal ini berarti bahwa sumbangan variasi naik turunnya ROS sebesar $54.8 \%$ sedangkan sisanya sebesar $45.2 \%$ dipengaruhi oleh variabel lain yang tidak dipergunakan dalam penelitian ini.
ROS dengan nilai signifikansit masing-masing sebesar 0.000 yang lebih kecil dari $\alpha(0.05)$. Hal ini berarti secara parsial SIZE dan LEV berpengaruh signifikan terhadap ROS.

\section{Kinerja yang Diukur Menggunakan ROI}

Hasil perhitungan pada Tabel 6 menunjukkan bahwa signifikansi F bernilai 0.000 lebih kecil dari $\alpha$

Tabel 5. Hasil Analisis Regresi Linier Berganda- Uji t (Variabel Terikat ROS)

\begin{tabular}{|c|c|c|c|c|c|c|}
\hline & \multicolumn{6}{|c|}{ Coefficients $^{a}$} \\
\hline & \multirow{2}{*}{ Model } & \multicolumn{2}{|c|}{ Unstandardized Coefficients } & \multirow{2}{*}{$\begin{array}{c}\begin{array}{c}\text { Standardized } \\
\text { Coefficients }\end{array} \\
\text { Beta }\end{array}$} & \multirow[t]{2}{*}{$\mathbf{T}$} & \multirow{2}{*}{ Sig. } \\
\hline & & B & Std. Error & & & \\
\hline \multirow[t]{5}{*}{1} & (Constant) & -.360 & .114 & & -3.168 & .003 \\
\hline & SS & .000 & .001 & .062 & .590 & .558 \\
\hline & PS & .003 & .001 & .371 & 3.443 & .001 \\
\hline & SIZE & .065 & .015 & .541 & 4.291 & .000 \\
\hline & LEV & -.183 & .043 & .493 & -4.207 & .000 \\
\hline
\end{tabular}

a. Dependent Variable: ROS

Hasil perhitungan pada Tabel 5 menunjukan bahwa secara parsial, variabel bebas PS berpengaruh signifikan terhadap ROS dengan nilai signifikansi $\mathrm{t}$ sebesar 0.001 yang lebih kecil dari $\alpha(0.05)$. Hal ini berarti secara parsial PS berpengaruh signifikan terhadap ROS. Sedangkan variabel bebas lainnya, yaitu SS tidak berpengaruh signifikan terhadap ROS dengan nilai signifikansi t sebesar 0.558 yang lebih besar dari $\alpha(0.05)$. Hal ini berarti secara parsial SS tidak berpengaruh signifikan terhadap ROS.

Sementara itu semua variabel kontrol (SIZE dan LEV) secara parsial berpengaruh signifikan terhadap
(0.05), yang berarti semua variabel bebas berpengaruh signifikan terhadap variabel terikat, sehingga dapat dikatakan bahwa Ho ditolak atau Ha diterima atau dengan kata lain PS, SS LEV, dan SIZE secara simultan mempunyai pengaruh signifikan terhadap ROI.

Dari hasil perhitungan pada Tabel 7 diperoleh nilai $\mathrm{R}^{2}$ sebesar 0.540 (54.0\%). Hal ini berarti bahwa sumbangan variasi naik turunnya PS,SS, LEV, dan SIZE mempunyai pengaruh terhadap variasi naik turunnya ROI sebesar $54.0 \%$ sedangkan sisanya sebesar $46.0 \%$ dipengaruhi oleh variabel lain yang tidak dipergunakan dalam penelitian ini. 
Tabel 6. Hasil Analisis Linier Berganda-Uji F(Variabel Terikat ROI)

ANOVA $^{\text {b }}$

\begin{tabular}{|c|c|c|c|c|c|c|}
\hline \multicolumn{2}{|c|}{ Model } & Sum of Squares & \multirow[t]{2}{*}{ Df } & Mean Square & \multirow{2}{*}{$\frac{\mathbf{F}}{13.782}$} & \multirow{2}{*}{$\begin{array}{l}\text { Sig. } \\
.000\end{array}$} \\
\hline 1 & Regression & .316 & & .079 & & \\
\hline & Residual & .270 & 47 & .006 & & \\
\hline & Total & .586 & 51 & & & \\
\hline
\end{tabular}

a. Predictors: (Constant), LEV, SS, PS,SIZE

b. Dependent Variable: ROI

Tabel 7. Hasil Analisi Regresi Linier Berganda-R Square (Variabel Terikat ROI)

Model Summary ${ }^{b}$

\begin{tabular}{|c|c|c|c|c|c|}
\hline Model & $\mathbf{R}$ & R Square & $\begin{array}{l}\text { Adjusted R } \\
\text { Square }\end{array}$ & $\begin{array}{l}\text { Std. Error of the } \\
\text { Estimate }\end{array}$ & Durbin-Watson \\
\hline 1 & $.735^{\mathrm{a}}$ & .540 & .501 & .0757517763 & \\
\hline
\end{tabular}

Tabel 8. Hasil Analisis Regresi Linier Berganda-Uji t (Variabel Terikat ROI)

\begin{tabular}{|c|c|c|c|c|c|c|}
\hline & \multicolumn{6}{|c|}{ Coefficients $^{\mathrm{a}}$} \\
\hline & \multirow[t]{2}{*}{ Model } & \multicolumn{2}{|c|}{ Unstandardized Coefficients } & \multirow{2}{*}{$\begin{array}{c}\begin{array}{c}\text { Standardized } \\
\text { Coefficients }\end{array} \\
\text { Beta } \\
\end{array}$} & \multirow[t]{2}{*}{$\mathbf{t}$} & \multirow[t]{2}{*}{ Sig. } \\
\hline & & B & Std. Er ror & & & \\
\hline \multirow[t]{5}{*}{1} & (Constant) & .167 & .123 & & 1.363 & .179 \\
\hline & SS & .000 & .001 & .024 & -.223 & .825 \\
\hline & PS & .003 & .001 & .347 & 3.194 & .003 \\
\hline & SIZE & -.005 & .016 & .036 & -.284 & .778 \\
\hline & LEV & -.237 & .047 & .596 & -5.046 & .000 \\
\hline
\end{tabular}

a. Dependent Variable: ROI

Hasil perhitungan pada Tabel 8 menunjukkan bahwa secara parsial, variabel bebas PS berpengaruh signifikan terhadap ROS dengan nilai signifikansi t sebesar 0.003 yang lebih kecil dari $\alpha(0.05)$. Hal ini berarti secara parsial PS berpengaruh signifikan terhadap ROI. Sedangkan variabel bebas lainnya, yaitu SS tidak berpengaruh signifikan terhadap ROI dengan nilai signifikan $\mathrm{t}$ sebesar 0.825 yang lebih besar dari $\alpha(0.05)$. Hal ini berarti secara parsial SS tidak berpengaruh signifikan terhadap ROI.

Sementara itu variabel kontrol LEV secara parsial berpengaruh signifikan terhadap ROI dengan nilai signifikansi t sebesar 0.000 yang lebih kecil dari $\alpha$ (0.05). Hal ini berarti secara parsial LEV berpengaruh signifikan terhadap ROI. Sedangkan variabel kontrol lainnya, yaitu SIZE secara parsial tidak berpengaruh signifikan terhadap ROI dengan nilai signifikansi terhadap ROI dengan nilai signifikansi t sebesar 0.778 yang lebih besar dari $\alpha(0.05)$. Hal ini berarti secara parsial SIZE tidak berpengaruh signifikan terhadap ROI.

\section{Kinerja yang Diukur Menggunakan ROE}

Hasil perhitungan pada Tabel 9. Menunjukkan bahwa signifikansi F bernilai 0.000 lebih kecil dari $\alpha$

Tabel 9. Hasil Analisis Regresi Linier Berganda-Uji F(Variabel Terikat ROE)

\begin{tabular}{llrrrrr}
\hline \multicolumn{7}{c}{ ANOVA $^{\mathbf{b}}$} \\
\hline Model & & Sum of Squares & df & Mean Square & F & Sig. \\
\hline 1 & Regression & .482 & 4 & .120 & 9.932 & $.000^{\text {a }}$ \\
& Residual & .570 & 47 & .012 & & \\
\hline & Total & 1.052 & 51 & & \\
\hline
\end{tabular}

a. Predictors: (Constant), LEV, SS, PS,SIZE

b. Dependent Variable: ROE 
(0.05), yang berarti semua variabel bebas berpengaruh signifikan terhadap variabel terikat, sehingga dapat dikatakan bahwa Ho ditolak atau Ha diterima atau dengan kata lain PS, SS, LEV, dan SIZE secara simultan mempunyai pengaruh signifikan terhadap ROE. sebesar 0.310 yang lebih besar dari $\alpha(0.05)$. Hal ini berarti secara parsial SIZE tidak berpengaruh signifikan terhadap ROI.

Tabel 10. Hasil Analisi Regresi Linier Berganda-R Square (Variabel Terikat ROE)

\begin{tabular}{llrrrrr}
\multicolumn{7}{c}{ Model Summary $^{\mathbf{b}}$} \\
\hline Model & \multicolumn{1}{l}{ R } & \multicolumn{2}{c}{ R Square } & $\begin{array}{c}\text { Adjusted R } \\
\text { Square }\end{array}$ & $\begin{array}{c}\text { Std. Error of the } \\
\text { Estimate }\end{array}$ & \multicolumn{2}{c}{ Durbin-Watson } \\
\hline 1 & $.677^{\mathrm{a}}$ & .458 & & .412 & .1101335519 & 1.894 \\
\hline
\end{tabular}

a. Predictors: (Constant), LEV, SS, PS, SIZE

b. Dependent Variable: ROE

Dari hasil perhitungan pada Tabel 10. Diperoleh nilai $\mathrm{R}^{2}$ sebesar 0.458 (45.8\%). Hal ini berarti bahwa sumbangan variasi naik turunnya PS, SS, LEV dan SIZE mempunyai pengaruh terhadap variasi naik turunnya ROE sebesar $45.8 \%$ sedangkan sisanya sebesar $54.2 \%$ dipengaruhi oleh variabel lain yang tidak dipergunakan dalam penelitian ini.

\section{Kinerja yang Diukur Menggunakan SALEFF}

Berikut ini hasil dari analisis regresi linier berganda, pada tabel 12 .

Hasil perhitungan pada Tabel 12 menunjukkan bahwa signifikansi F bernilai 0.001 lebih kecil dari $\alpha$ (0.05), yang berarti semua variabel bebas berpengaruh

Tabel 11. Hasil Analisis Regresi Linier Berganda - Uji t (Variabel Terikat ROE)

\section{Coefficients $^{\mathrm{a}}$}

\begin{tabular}{|c|c|c|c|c|c|c|}
\hline & \multirow{2}{*}{ Model } & \multicolumn{2}{|c|}{ Unstandardized Coefficients } & \multirow{2}{*}{$\begin{array}{c}\begin{array}{c}\text { Standardized } \\
\text { Coefficients }\end{array} \\
\text { Beta }\end{array}$} & \multirow[t]{2}{*}{$\mathbf{t}$} & \multirow{2}{*}{ Sig. } \\
\hline & & B & Std. Error & & & \\
\hline \multirow[t]{5}{*}{1} & (Constant) & -.099 & .179 & & -.553 & .583 \\
\hline & SS & $8.153 \mathrm{E}-6$ & .001 & .001 & .009 & .993 \\
\hline & PS & .007 & .001 & .551 & 4.677 & .000 \\
\hline & SIZE & .024 & .024 & .142 & 1.027 & .310 \\
\hline & LEV & -.163 & .068 & -.305 & -2.383 & .021 \\
\hline
\end{tabular}

a. Dependent Variable: ROE

Hasil perhitungan pada Tabel 11 menunjukkan bahwa secara parsial, variabel bebas PS berpengaruh signifikan terhadap ROE dengan nilai signifikansi t sebesar 0.000 yang lebih kecil dari $\alpha(0.05)$. Hal ini berarti secara parsial PS berpengaruh signifikan terhadap ROE. Sedangkan variabel bebas lainnya, yaitu SS tidak berpengaruh signifikan terhadap ROE dengan nilai signifikan t sebesar 0.993 yang lebih besar dari $\alpha(0.05)$. Hal ini berarti secara parsial SS tidak berpengaruh signifikan terhadap ROE.

Sementara itu variabel kontrol LEV secara parsial berpengaruh signifikan terhadap ROE dengan nilai signifikan $\mathrm{t}$ sebesar 0.021 yang lebih kecil dari $\alpha$ (0.05). Hal ini berarti secara parsial LEV berpengaruh signifikan terhadap ROI. Sedangkan variabel kontrol lainnya, yaitu SIZE secara parsial tidak berpengaruh signifikan terhadap ROI dengan nilai signifikan $t$ signifikan terhadap variabel terikat, sehingga dapat dikatakan bahwa Ho ditolak atau Ha diterima atau dengan kata lain PS,SS LEV, SIZE dan SIZE secara simultan mempunyai pengaruh signifikan terhadap SALEFF.

Dari hasil perhitungan pada Tabel 13 diperoleh nilai $\mathrm{R}^{2}$ sebesar 0.329 (32.9\%). Hal ini berarti bahwa sumbangan variasi naik turunnya SALEFF sebesar $32.9 \%$ sedangkan sisanya sebesar $67.1 \%$ dipengaruhi oleh variabel lain yang tidak digunakan dalam penelitian ini.

Perhitungan pada tabel 14 menunjukkan bahwa secara parsial, variabel SS dan PS berpengaruh terhadap SALEFF dengan nilai signifikansi t masing-masing sebesar 0.020 dan 0.001 yang lebih kecil dari $\alpha(0.05)$. Hal ini berarti secara parsial SS dan PS berpengaruh signifikan terhadap SALEFF. Sementara itu variabel 
Privatisasi Struktur Kepemilikan, dan Kinerja Bumn di Indonesia

Tabel 12. Hasil Analisis Regresi Linier Berganda-Uji F(Variabel Terikat SALEFF)

ANOVA $^{b}$

\begin{tabular}{|c|c|c|c|c|c|c|}
\hline \multicolumn{2}{|c|}{ Model } & Sum of Squares & \multirow[t]{2}{*}{ df } & Mean Square & \multirow{2}{*}{ F } & \multirow{2}{*}{$\begin{array}{l}\text { Sig. } \\
.001^{\mathrm{a}}\end{array}$} \\
\hline 1 & Regression & 96.228 & & 24.057 & & \\
\hline & Residual & 195.916 & 47 & 4.168 & & \\
\hline & Total & 292.144 & 51 & & & \\
\hline
\end{tabular}

a. Predictors: (Constant), LEV, SS, PS,SIZE

b. Dependent Variable: SALEFF

Tabel 13. Hasil Analisi Regresi Linier Berganda-R Square (Variabel Terikat SALEFF)

Model Summary $^{\text {b }}$

\begin{tabular}{crrrrr}
\hline Model & R & R Square & $\begin{array}{c}\text { Adjusted R } \\
\text { Square }\end{array}$ & $\begin{array}{c}\text { Std. Error of the } \\
\text { Estimate }\end{array}$ & \multicolumn{2}{c}{ Durbin-Watson } \\
\hline 1 & $.677^{\mathrm{a}}$ & .458 & .412 & .1101335519 & 1.894 \\
\hline
\end{tabular}

a. Predictors: (Constant), LEV, SS, PS, SIZE

b. Dependent Variable: ROE

Tabel 14. Hasil Analisis Regresi Linier Berganda - Uji t (Variabel Terikat SALEFF)

Coefficients ${ }^{\mathrm{a}}$

\begin{tabular}{|c|c|c|c|c|c|c|}
\hline & \multirow{2}{*}{ Model } & \multicolumn{2}{|c|}{ Unstandardized Coefficients } & \multirow{2}{*}{$\begin{array}{c}\begin{array}{c}\text { Standardized } \\
\text { Coefficients }\end{array} \\
\text { Beta } \\
\end{array}$} & \multirow[t]{2}{*}{$\mathbf{t}$} & \multirow[t]{2}{*}{ Sig. } \\
\hline & & B & Std. Error & & & \\
\hline \multirow[t]{5}{*}{1} & (Constant) & 9.933 & 3.312 & & 2.999 & .004 \\
\hline & SS & -.042 & .017 & -.310 & -2.410 & .020 \\
\hline & PS & .102 & .028 & .483 & 3.683 & .001 \\
\hline & SIZE & -1.307 & .440 & -.456 & -2.970 & .005 \\
\hline & LEV & 2.917 & 1.267 & .328 & 2.303 & .026 \\
\hline
\end{tabular}

a. Variable: $S A L E F F$

kontrol SIZE dan LEV secara parsial berpengaruh signifikan terhadap SALEFF dengan nilai signifikan t masing-masing sebesar 0.005 dan 0.026 yang lebih kecil dari $\alpha(0.05)$. Hal ini berarti secara parsial SIZE dan LEV berpengaruh signifikan terhadap SALEFF.

Beragamnya hasil analisis dari masing-masing variabel terikat, ditunjukan dalam rangkuman berikut ini:
SALEFF. Hal ini berarti hipotesis yang diajukan, bahwa kepemilikan publik (PS) mempengaruhi kinerja (ROS, ROI, ROE, dan SALEFF) BUMN setelah privatisasi, adalah terbukti benar atau diterima. Adapun besarnya pengaruh kepemilikan publik terhadap kinerja, berturut-turut untuk ROS sebesar 0.548 (54.8\%), ROI sebesar 0.540 (54\%), ROE sebesar 0.458 (45.8\%) dan

Tabel 15. Rangkuman Hasil Analisis Regresi Linier Berganda (Uji F dan Uji t)

\begin{tabular}{llllll}
\hline & & ROS & ROI & ROE & SALEFF \\
\hline R Square & & 0.548 & 0.540 & 0.458 & 0.329 \\
Sig F & & 0.000 & 0.000 & 0.000 & 0.001 \\
& SS & 0.558 & 0.825 & 0.993 & 0.020 \\
& PS & 0.001 & 0.003 & 0.000 & 0.001 \\
Sig t & SIZE & 0.000 & 0.778 & 0.310 & 0.005 \\
& LEV & 0.000 & 0.000 & 0.021 & 0.026 \\
\hline
\end{tabular}

Berdasarkan Tabel 15 ditunjukkan bahwa PS secara parsial berpengaruh signifikan terhadap kinerja yang diukur menggunakan ROS, ROI, ROE dan
SALEFF sebesar 0.329 (32.9\%). Pengaruh terbesar kepemilikan publik terhadap kinerja, adalah kinerja yang diukur menggunakan ROS (54.8\%) dan terkecil adalah SALEFF (32.9\%). 


\section{PEMBAHASAN}

Berdasarkan hasil analisis data dan setelah dilakukan pengujian hipotesis dalam penelitian ini, ditunjukan bahwa terdapat pengaruh kepemilikan publik terhadap kinerja BUMN setelah privatisasi. Kepemilikan publik merupakan besarnya presentase saham BUMN hasil privatisasi yang dimiliki publik, besarnya berada pada kisaran $9.97 \%$ sampai dengan $48.99 \%$ sehingga diperoleh nilai rata-rata (mean) sebesar $32.22 \%$. Hal ini menggambarkan bahwa walaupun BUMN sudah diprivatisasi, kepemilikan publik belum menunjukkan angka mayoritas (masih minoritas).

Dalam penelitian ini kinerja diukur menggunakan ukuran profitabilitas (profitability) dan efisiensi operasi (operating efficiency). Profitabilitas diukur menggunakan ROS, ROI, ROE, dan SALEFF. Pengaruh terbesar ditunjukkan oleh kinerja yang diukur menggunakan ROS, sedangkan pengaruh terkecil ditunjukan oleh kinerja yang diukur menggunakan SALEFF.

ROS (Return On Sales) merupakan ukuran kinerja (profitabilitas) yang menunjukkan kemampuan penjualan atau pendapatan BUMN setelah privatisasi dalam menghasilkan laba bersih setelah pajak. ROS disebut juga dengan Net Profit Margin (NPM). Kemampuan penjualan atau pendapatan dalam menghasilkan laba bersih menunjukkan bahwa manajemen dapat mengelola BUMN setelah privatisasi dengan baik. Para calon pemegang saham tertarik dengan ROS yang besar, karena hal ini merupakan salah satu indikator keberhasilan suatu perusahaan, yaitu membaiknya kinerja penjualan perusahaan. Besarnya ROS pada BUMN setelah privatisasi berada pada kisaran $0.19 \%$ sampai dengan $42.63 \%$ sehingga diperoleh nilai rata-rata (mean) sebesar $13.91 \%$. Hal ini menggambarkan profitabilitas yang diukur melalui kemampuan penjualan dalam menghasilkan laba bersih setelah pajak relatif kecil. Hasil penelitian ini mendukung penelitian yang telah dilakukan oleh D'Souza dan Megginson (1999); La Porta, et al. (1999); dan Boubakri, et al. (2005b).

SALEFF (Sales Eficiency) merupakan ukuran kinerja (efisiensi operasi) yang menunjukkan efisiensi penjualan atau pendapatan, diukur menggunakan perimbangan antara penjual atau pendapatan dengan jumlah karyawan BUMN hasil privatisasi. Hal ini menggambarkan besarnya kemampuan seluruh karyawan BUMN hasil privatisasi dalam menghasilkan penjualan atau pendapatan. Para calon pemegang saham tertarik dengan SALEFF yang besar karena menunjukkan semakin efisiensinya operasi BUMN hasil privatisasi, yang membandingkan penjualan atau pendapatan terhadap jumlah karyawan yang bekerja didalamnya. Hasil penelitian menunjukan SALEFF berada pada kisaran nilai 0.44 kali sampai dengan 11.8 kali, sehingga diperoleh nilai rata-rata (mean) sebesar 2.74 kali. Hal ini menggambarkan efisiensi operasi relatif kecil. Hasil penelitian ini mendukung penelitian yang dilakukan oleh Boubakri dan Cossett (1998); D’Souza dan Megginson (1999); La Porta, et al. (1999); Frydman, et al. (1999); Dewenter dan Malatesta (2001); dan Boubakri, et al. (2005b).

\section{KESIMPULAN DAN SARAN}

\section{Kesimpulan}

Hasil penelitian sehubungan dengan Privatisasi, Struktur Kepemilikan, dan Kinerja BUMN di Indonesia, dapat disimpulkan sebagai berikut: (1) kepemilikan publik secara parsial berpengaruh signifikan terhadap kinerja BUMN setelah privatisasi yang diukur menggunakan ROS, ROI, ROE dan SALEFF, sehingga hipotesis yang diajukan terbukti benar. Pengaruh kepemilikan publik terhadap kinerja BUMN setelah privatisasi terbesar ditunjukkan oleh kinerja yang diukur menggunakan ROS dan terkecil adalah SALEFF. (2) ROS merupakan ukuran kinerja (profitabilitas) yang menunjukkan kemampuan penjualan atau pendapatan BUMN setelah privatisasi dalam menghasilkan laba bersih setelah pajak. Para calon pemegang saham tertarik dengan ROS yang besar, karena hal ini merupakan salah satu indikator keberhasilan suatu perusahaan dan manajemen dapat mengelola BUMN setelah privatisasi dengan baik. (3) SALEFF merupakan ukuran kinerja (efisiensi operasi) yang menunjukkan efisiensi penjualan atau pendapatan, diukur menggunakan perimbangan antara penjualan atau pendapatan dengan jumlah karyawan BUMN hasil privatisasi. Hal ini menggambarkan besarnya kemampuan seluruh karyawan BUMN hasil privatisasi dalam menghasilkan penjualan atau pendapatan. Para calon pemegang saham tertarik dengan SALEFF yang besar karena menunjukkan semakin efisiensinya operasi BUMN hasil privatisasi, yang membandingkan penjualan atau pendapatan terhadap jumlah karyawan yang bekerja di dalamnya.

\section{Saran}

Berdasarkan simpulan di atas dan data yang diperoleh beserta hasil perhitungan dan pengujiannya, dapat dikemukakan saran-saran sebagai berikut: (1) Perlu tindakan atau strategi dari pihak manajemen untuk lebih mampu meningkatkan penjualan atau 
pendapatan dengan mengefisiensikan biaya agar laba yang diperoleh menjadi meningkat. (2) Pihak manajemen BUMN hasil privatisasi perlu untuk lebih memperhatikan kepentingan karyawan terutama untuk kesejahteraan agar dapat lebih menjadi manusia yang bersumberdaya. (3) Penelitian ini masih terbatas pada struktur kepemilikan yang mempengaruhi kinerja perusahaan dengan ukuran perusahaan dan kebijakan hutang sebagai variabel kontrolnya. Diharapakan peneliti berikutnya menggunakan ukuran kinerja lainnya sebagai variabel terikat, sehingga dapat diketahui lebih jauh pengaruhnya. Selain itu dapat dipergunakan variabel kontrol lainnya, seperti umur perusahaan, jenis perusahaan, dan tingkat pertumbuhan perusahaan.

\section{DAFTAR RUJUKAN}

Boubakri, N., and Cosset, J.C. 1996. The Financial and Operating Performance of Newly Privatized Firms: Evidence From Developing Countries. Faculte des Sciences de I'administration. Universite Laval. Quebec, Canada.

Boubakri, N., Cosset, J.C. 1998. The Financial and Operating Performance of Newly Privatized Firms: Evidence From Developing Countries. Journal of Finance 53, 1081-1110.

Boubakri, N., Cosset, J.C., Guedhami, O. 2005. Postprivatization Corporate Governance: The Role of Ownership Structure and Investor Protection. Journal of Financial Economics 76, 369-399.

D' Souza, J., and Megginson, William, L. 1999. The Financial and Operating Performance of Privatized Firm During The 1990s. Forthcoming, Journal of Finance (August 1999).

Dewenter, Kathryn, M., and Paul, H.M. 2001. Firm ownership and perfor- mance, American Economic Review 91,320-334.

Dockner, Engelbert, J., Mosburger, G., Schahauser-Linzatti, Michaela, M. 2005. The Financial and Operating Performance of Privatized Firm in Austria.
Department of Finance \& Department of Business Administration, University of Vienna, BrAunnerStrabe. Vienna. Austria.

Gujarati, D.N. 1998. Basic econometrics. ( $3^{\text {rd }}$ ed.). McGRAW-HILL, New York, USA.

Gujarati, D.N. 2003. Basic econometrics. (4 $\left.{ }^{\text {rd }} \mathrm{ed}\right)$. NewYork: Mc Graw-Hill Companies, Inc.

Huang, Samuel, G.H., Song, Frank, M. 2002.The Financial and Operating Performance of China's Newly Listed H-Firms. School of Economics and Finance. Faculty of Business and Economics. The University of Hong Kong, Pokfulam Road. Hong Kong.

http://jurnal-ekonomi.org/2008/02/06/bom-privatisasi-Indonesia-2008/ Perampokan Harta Negara

http://cafe-ekonomi.blogspot.com/2009/05/restrukturisasidan-privatisasi-bumn.html

Indriantoro, N., dan Supomo, B. 2002. Metodologi Penelitian Bisnis Untuk Akuntansi dan Manajemen. Edisi Pertama. Cetakan Kedua. Yogyakarta: BPFE.

La Porta, R., Lopez-de-Silanes, F., Shleifer, A. 1999. Corporate ownership around the world. Journal of Finance 54, 471-517.

Li, D., Moshirian, F., Nguyen, Pascal, Tan, Li-Wen. 2007. "Managerial Ownership and Firm Performance: Evidence from China's Privitazions". Research in Internasional Business and Finance 21. Page 396413.

Mathur, I., and Banchuenvijit, W. 2007. "The Effects of Privatization on The Performance of Newly Privatized Firm in Emerging Markets". Emerging Markets Review 8 (2007) pages 134-146

Pandu, P. http://www.google.com/privatisasi

Santoso, S. 2001. Statistik Multivariat. Jakarta: Penerbit PT Elex Media Komputindo.

Sugiyono. 2001. Metode Penelitian Administrasi. Bandung: Penerbit Alfabeta.

Sun, Q., Tong, Wilson, H.S., and Tong, J. 2002. "How Does Government Ownership Affect Firm Performance? Evidence from China's Privatization Experience". Journal of Business Finance and Accounting. 29 (1). January/ March. Page 1-27'

www.wikipedia.com 